\title{
Farmers' Perception and Impact of Rice Yellow Mottle Disease on Rice Yields in Burkina Faso
}

\author{
Valentin S. E. Traoré ${ }^{*}$, Bouma James Néya ${ }^{1}$, Mouhameth Camara², Vernon Gracen³, \\ Samuel K. Offei ${ }^{3}$, Oumar Traoré ${ }^{1}$ \\ ${ }^{1}$ Institut de I'Environnement et de Recherches Agricoles (INERA), Ouagadougou, Burkina Faso \\ ${ }^{2}$ Institut Supérieur de Formation Agricole et Rurale (ISFAR), Université de Thiès, Bambey, Sénégal \\ ${ }^{3}$ West African Centre for Crop Improvement (WACCI), University of Ghana, Legon, Ghana \\ Email: traorevalentin@gmail.com
}

Received 17 August 2015; accepted 14 September 2015; published 18 September 2015

Copyright (C) 2015 by authors and Scientific Research Publishing Inc.

This work is licensed under the Creative Commons Attribution International License (CC BY).

http://creativecommons.org/licenses/by/4.0/

(c) () Open Access

\begin{abstract}
Rice improvement for disease resistance has scarcely involved farmers' knowledge in Sub-Saharan Africa. A participatory rural appraisal was conducted in two main rice cultivation areas in Burkina Faso to assess farmers' awareness of rice production constraints with emphasis on rice yellow mottle disease (RYMD) and its management. Farmers' preference for rice varieties to be used in the breeding program was also assessed. Major concerns for rice cultivation as perceived by farmers were water shortage and RYMD. However, relative importance of each constraint depended on the survey areas, RYMD being prominent at Banzon while water shortage predominated at Mogtedo. Mogtedo farmers preferred rice variety FKR19 because of its tolerance to drought. At Banzon, farmers' first criterion was taste which was reflected in the choice of variety FKR18. Yield was also a major criterion in both areas, positioning NERICA varieties FKR56N, FKR62N, and FKR60N among the top preferred varieties. Farmers mentioned RYMD as the most important rice disease. Most farmers used varietal shifts or pesticide treatments for RYMD management. RYMD incidence reached 28\% in average at Banzon over the 2012-2013 main growing seasons. In rice varieties FKR56N, FKR62N and TS2, diseased plants yielded $79.3 \%$ less than the healthy ones. Accordingly, based on disease incidence, overall yield loss in the study area was estimated at $\mathbf{2 2 . 3 \%}$. Altogether, rice production can be significantly increased by taking RYMD into account in a participatory rice breeding strategy.
\end{abstract}

\section{Keywords}

Farmers' Knowledge, Disease Management, Preferred Varieties, Yield Loss

\footnotetext{
${ }^{*}$ Corresponding author.
}

How to cite this paper: Traoré, V.S.E., Néya, B.J., Camara, M., Gracen, V., Offei, S.K. and Traoré, O. (2015) Farmers' Perception and Impact of Rice Yellow Mottle Disease on Rice Yields in Burkina Faso. Agricultural Sciences, 6, 943-952. 


\section{Introduction}

Rice (Oryza sativa L. and O. glaberrima Steud.) is a major food crop in Sub-Saharan Africa (SSA) where it plays a key role for food security. In 2013, the overall paddy rice production in the region was estimated at 22.4 million tons (http://faostat3.fao.org), which cover only half of the consumption needs. Rice demand has more than tripled from 1.9 to 5.8 million tons over the past two decades in SSA countries [1] [2]. Following the recent food crisis [3], several West African countries adopted strategies for increasing rice production. These included large scale use of improved seeds, better technical assistance to rice farmers and increase of rice cultivation areas.

Since the early 1990s, rice production has been severely affected by rice yellow mottle disease caused by Rice yellow mottle virus (RYMV) [4]. The disease is widespread in most rice growing countries in Africa including Madagascar. RYMV is non-seed transmissible in rice and wild host species [5] [6]. However, it is known as a highly infectious and very stable virus transmitted by several means including wind, insects, mammals and man [7]-[9]. Significant yield losses induced by RYMV (25\% - 100\%) have been reported by several authors, although most studies were done under experimental conditions [4] [10]-[13]. Rice genotype and age of rice plants during infection have been shown to be major factors influencing yield reduction.

Most cultivated rice varieties have been reported as highly susceptible [14]. Attempts to control rice yellow mottle disease have been mainly directed to breeding for resistance to RYMV [15]. A few sources of resistance to be used in breeding programs were identified [14]-[17]. However, the durability of such resistance was questioned, as resistance-breaking isolates of the virus were shown to occur frequently [18] [19]. Consequently, Traore et al. [20] concluded that integrated management strategies should be adopted for durable control of the disease. The use of insecticides was found to effectively control populations of some insect vectors [21]. However, chemical control of rice yellow mottle is economically unfeasible and possibly unsuccessful due to the large number vector species [20]. Consequently, sustainable management of the disease will rely mainly on genetic control and effective phytosanitary measures.

Farmers' involvement in the process of disease control can be of great importance in the success of management practices as exemplified by the wide application of farmers' field schools [22]. The development of integrated pest management (IPM) technologies for rice farmers in Asia has been relatively successful [23]. This success was attributed to extensive creation of farm-level awareness of pest and diseases and management strategies. By contrast, only a few similar studies have been conducted in Africa and this has probably limited the success of IPM implementation for sustainable rice production. In this paper we assessed farmers' awareness, perception and management practices of rice yellow mottle disease and the impact of RYMV on their preferred varieties.

\section{Material and Methods}

\subsection{Survey Areas}

In Burkina Faso, rice is mostly grown in two zones, including the moist savannah zone in the south (900 - 1200 $\mathrm{mm}$ annual rainfall) and the dry savannah $(600-900 \mathrm{~mm})$ in the central part of the country. Rice production systems include irrigated, lowland and rainfed rice. Rice yellow mottle disease occurs mainly in irrigated rice and in a lesser extent in lowland rice. In this study, surveys were conducted in two locations including Banzon $\left(11^{\circ} 19^{\prime} 0.00 " \mathrm{~N} ; 4^{\circ} 47^{\prime} 60.00^{\prime \prime} \mathrm{W}\right)$ and Mogtedo $\left(12^{\circ} 17^{\prime} 03.84^{\prime \prime N}\right.$; $\left.0^{\circ} 50^{\prime} 14.00^{\prime \prime} \mathrm{W}\right)$, representative of the moist and the dry savannah zones, respectively. In both locations, rice is grown under irrigation and rice yellow mottle disease occurs endemically. Banzon has a full irrigation system for growing rice all year round with water from a river. At Mogtedo, irrigation water is mostly from reservoirs fed by rainwater and located up stream. Availability of water for irrigation is therefore dependent on rainfall and there is more lowland and rainfed rice than at Banzon.

\subsection{Sampling Procedures and Data Collection}

Surveys were conducted using two complementary approaches: 1) questionnaires and 2) informal discussions with farmers in the field. A semi-structured questionnaire was used to guide discussions with farmers and to collect primary data. All interactions with farmers were done in local languages to ensure effective understanding. About 100 respondents selected at random using proportional sampling allocation technique were interviewed in each location. Farmers were included in the study if rice was their sole or main crop. Data were col- 
lected on farmers' awareness, perception and control of rice yellow mottle disease. Data on rice varieties grown by farmers as well as farmer's criteria for preference of rice varieties were also collected.

\subsection{Yield Loss and Disease Incidence Assessment}

Yield loss due to the virus were assessed in three rice varieties in Banzon locality during 2012 and 2013 main rice growing seasons spanning from June to October. For each rice variety, a total of 50 diseased plants and 50 symptomless plants were randomly selected in five distinct $500 \mathrm{~m}^{2}$-blocks which were at least $50 \mathrm{~m}$ apart. All plants were tagged with two different color labels. At maturity, rice grains from individual plants were harvested and dry seeds (11\% humidity) weighed. Yield losses were computed by comparing yields from healthy and diseased plants. Disease incidence was assessed in the whole perimeter regardless of rice varieties in five blocks which were $100 \mathrm{~m}$ apart. In each block, 1000 plants were randomly examined and diseased plants were counted.

\subsection{Data Analysis}

Data on farmer's interviews were recorded and analyzed using SPHINX-PLUS@ software version 4.5. Firstly, a frequency table of the responses with their percentages and means was used for a descriptive analysis of the variables. Then a cross tabulation of the variables were done to assess the correlations between farmers preference for rice varieties and other variables. Chi-square test with the standard level of significance $(P<0.05)$ was used for comparison of proportions. Significance of differences in mean yield losses between rice varieties were tested by analysis of variance (ANOVA) using Statistica $\odot$ software, version 6. Data on disease incidence were also analyzed by ANOVA after angular transformation [24].

\section{Results}

\subsection{Features of Rice Production}

Rice production in both Banzon and Mogtedo was dominated by male farmers (87.2\%). There were more female farmers in Mogtedo (22.3\%) than in Banzon (3.0\%). Most farmers appeared to have a long experience in rice cultivation since $87.2 \%$ have been producing rice for more than five years. Rice production was largely dominated by smallholders in both locations. About $98.5 \%$ of farmers cultivated fields ranging from 0.5 ha to less than 5 ha. Larger field sizes ( 5 to more than 10 ha) were held by only a few farmers. Most farmers ( $58 \%$ and $94 \%$ at Banzon and Mogtedo, respectively) experienced low yields of $1-2 \mathrm{t} / \mathrm{ha}$. Accordingly, $42 \%$ of Banzon farmers and only $6 \%$ of Mogtedo farmers recorded higher yields of $3-5 \mathrm{t} / \mathrm{ha}$. All farmers were also involved in the production of other crops including cereals, dry legumes and vegetables.

\subsection{Rice Varieties Grown and Farmers' Preferred Varieties}

A total of 13 rice varieties were inventoried in the two study areas which shared only six varieties (Figure 1). Most farmers indicated simultaneous cultivation of several varieties. The proportions of farmers using one, two or three varieties were $17.7 \%, 31 \%$ and $51.3 \%$, respectively. Varieties common to the two localities included FKR14, FKR19, FKR28 and three interspecific O. sativa x O. glaberrima derived NERICA varieties (FKR56N, FKR60N and FKR62N) [21]. The majority of farmers in Banzon (70.8\%) cited four varieties including FKR18, FKR19, FKR60N and FKR62N as the common varieties grown, FKR18 being the most common (20.4\%). However, FKR62N was quoted as the best yielding among NERICA varieties. At Mogtedo, FKR19, FKR56N, FKR60N and FKR62N were the most grown varieties (83.5\% of farmers). However, FKR19 clearly was favoured over the NERICA varieties as indicated by $42 \%$ of farmers.

In Banzon, farmers' preferred rice varieties somewhat matched the top grown varieties except for FKR19. The three NERICA varieties were part of the most preferred varieties, as $43 \%$ of farmers preferred them. Yet, most farmers (38\%) preferred FKR18, indicating a clear-cut choice for this variety. In Mogtedo, FKR19 was by far the most preferred variety chosen by $65 \%$ of farmers. NERICA varieties were also among Mogtedo farmers' top choices but to a lesser extent compared to Banzon. Hence, the proportion of farmers who preferred these varieties as a whole was only $24.3 \%$. Altogether, farmer's choice for rice varieties strongly depended on varieties they usually grew. This was apparent in both Banzon and Mogtedo $(\mathrm{P}<0.001)$.

The underlying criteria driving farmers' preference for rice varieties varied in the different localities surveyed. 


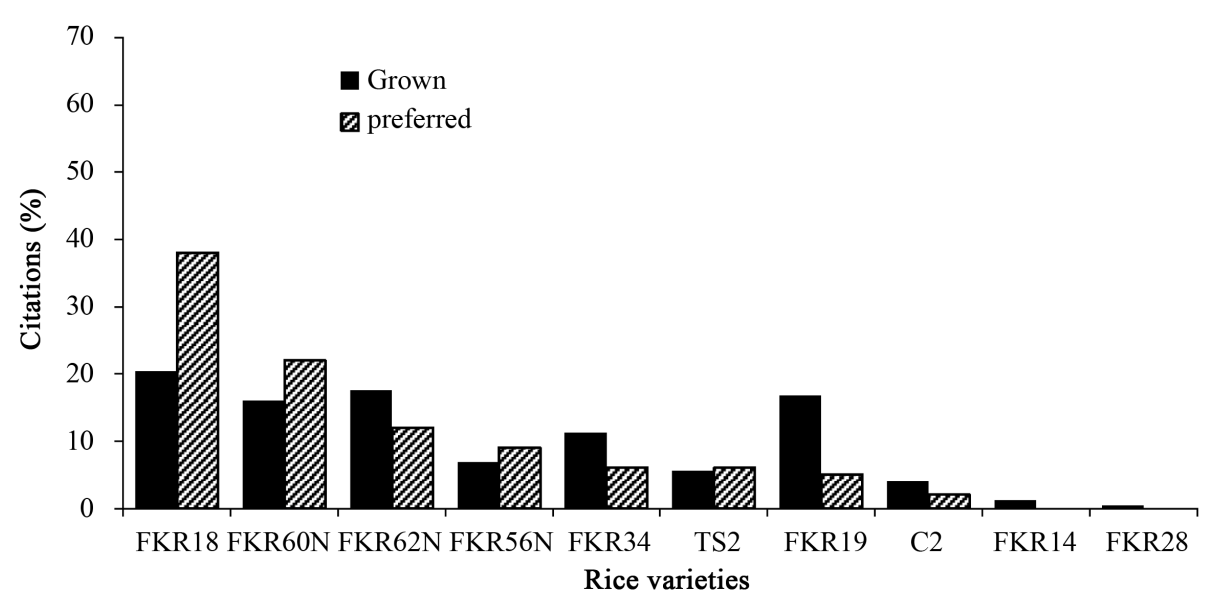

(a)

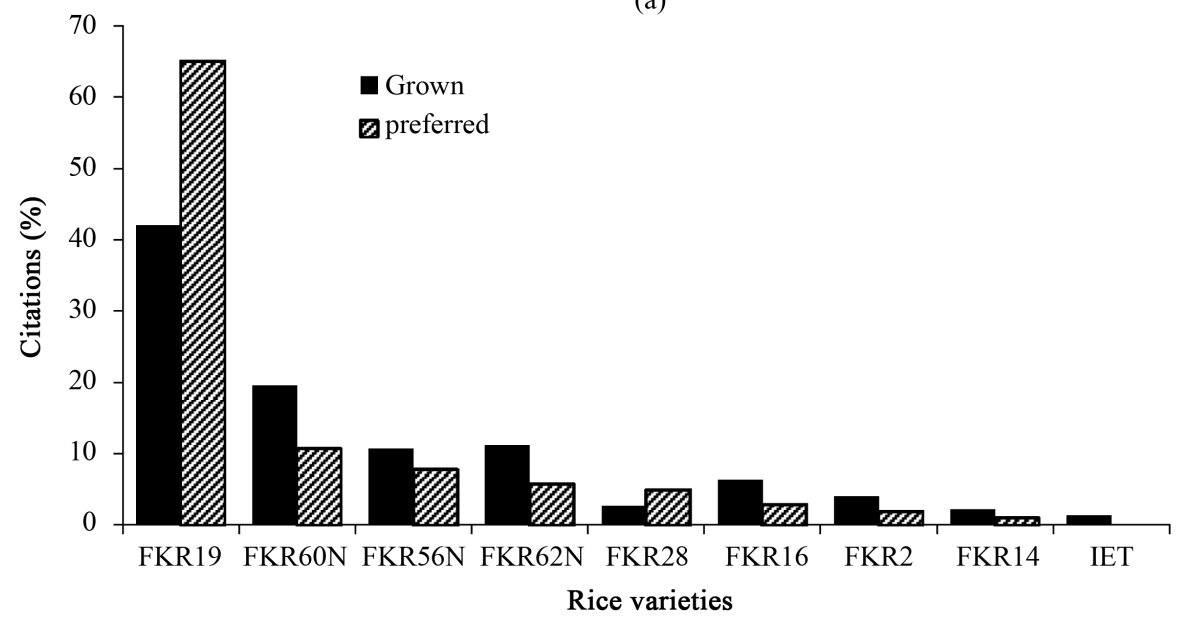

(b)

Figure 1. Rice varieties grown and farmers’ preferred varieties in Banzon (a) and Mogtedo (b).

In Banzon and Mogtedo, high yielding and high market value varieties were among the important criteria mentioned by farmers (Figure 2). Taste was the first criterion mentioned by farmers at Banzon. Other characteristics were disease resistance and availability of good seeds. Grain quality, resistance to pests and plant height and length of the growing period were considered to be of secondary importance. By contrast, farmers in Mogtedo stated yield as their foremost criterion. Although high market value varieties were among their primary criteria, length of the growing period and plant height were also important. All other factors including pest and disease resistance were minor.

\subsection{Major Constraints to Rice Production}

Prominent constraints to rice production mentioned by farmers at Banzon and Mogtedo were water availability and diseases (Figure 3). Lack of access to fertilizers and their high cost were considered as moderate constraints, particularly at Banzon. Other constraints including availability of quality seeds, lack of technical assistance and damage by insect pests, weeds, birds, and grazing mammals were referred to as less important. Water shortage and diseases were the most important constraints in Mogtedo. Moreover, constraints in this locality were of greater importance than in Banzon.

Rice yellow mottle disease was the most important disease cited by farmers at both Banzon and Mogtedo (Figure 4). Secondary diseases and pests included African gall midge (Orseolia oryzivora Harris \& Gagné [Diptera: Cecidomyiidae]) and rice blast. Iron toxicity was also mentioned, especially at Banzon, even though it was an abiotic stress. Some of the farmers were unaware of the occurrence of diseases. They recognized symptoms 


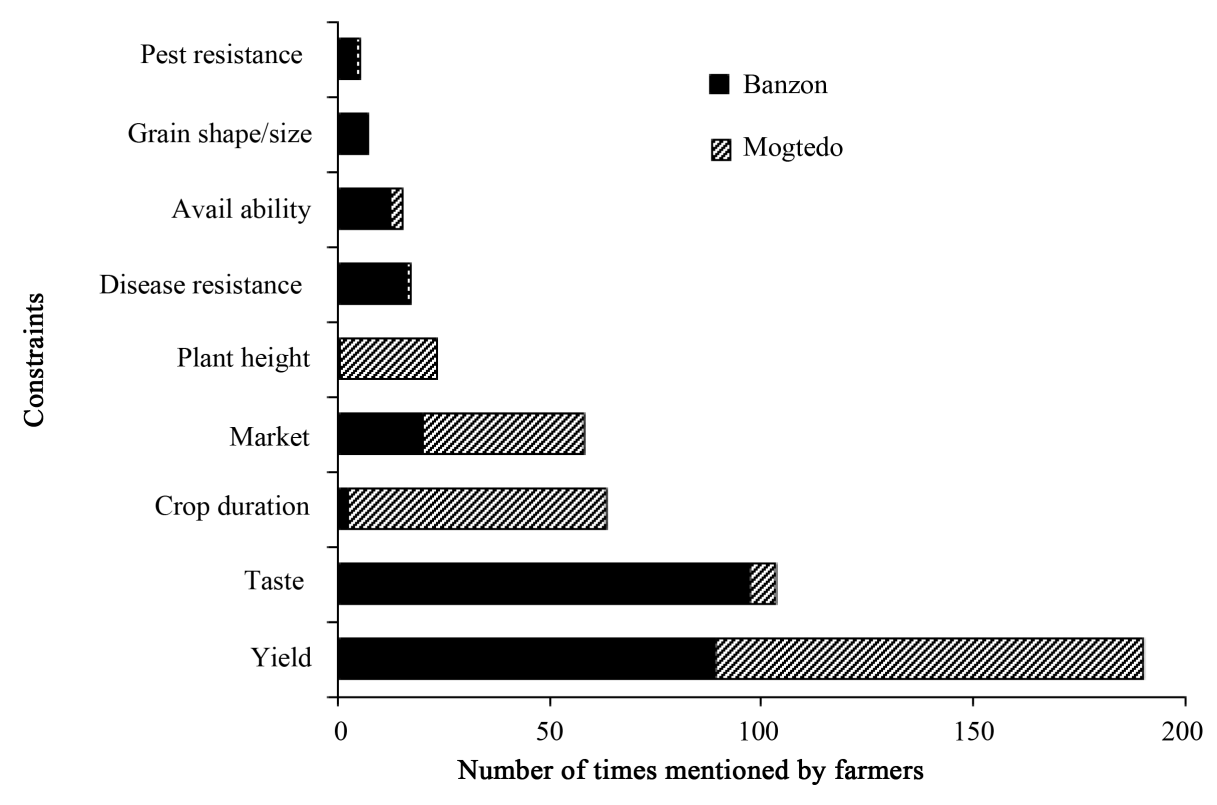

Figure 2. Criteria for rice varietal preference by farmers in Banzon and Mogtedo.

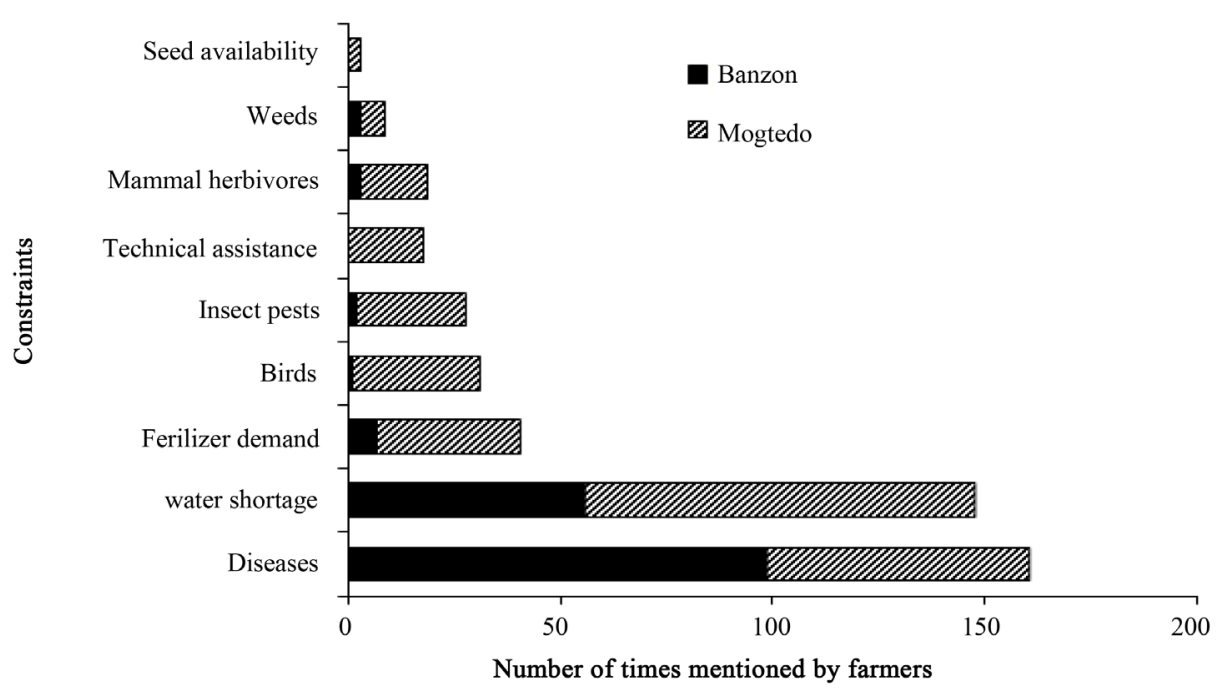

Figure 3. Main constraints to rice production mentioned by farmers at Banzon and Mogtedo.

but attributed them to different factors such as soil infertility, soil degradation or by ash coming from burned rice residues when cleaning the fields.

\subsection{Rice Yellow Mottle Disease and Its Management}

Farmers used expressive terms to refer to most important diseases they observed. Hence, rice yellow mottle was referred to as "rice HIV-AIDS" because like Human immunodeficiency virus, once a rice plant was infected, it remained so until death or harvest. In several instances, farmers did not give any particular name, but stated symptoms which might have been caused by RYMV. Such symptoms included "yellowing of the leaves", "plant stunting" "panicle sterility", cited alone or in combinations. Gall midge was referred to as "dead heart" or "antenna" to describe the characteristic onion shoots galls.

Up to $85 \%$ of farmers stated that they adopted at least one control measure against rice yellow mottle disease. Replacement of rice varieties and use of pesticides were some of the common control measures. Farmers indicated that no recommendations were given to them for the use of pesticides, yet they systematically adopted this 
measure blindly as first solution. Shifting varieties was more widespread at Banzon while pesticides application in rice fields was practiced at Mogtedo (Figure 5). Control methods adopted included cultural practices, use of pesticides and abandonment of the fields for one or two years. Cultural practices comprised disease avoidance through delay of sowing and transplanting dates, weeding rice fields as well as clearing levees and ditches around. Most farmers indicated that varietal shift and other cultural practices were recommended by extension agents although these recommendations were not usually effective because they continued to experience yield losses due to diseases.

\subsection{Yield Loss Assessment and Disease Incidence}

Yield loss due to rice yellow mottle disease was assessed for three rice varieties including FKR56N, FKR62N and TS2 (Table 1). Rice yellow mottle disease had a high impact on grain yield reduction. Average yield losses of approximately $75 \%, 79 \%$ and $84 \%$ were recorded in rice varieties TS2, FKR62N and FKR56N, respectively. Consequently, the overall yield loss induced by rice yellow mottle disease was estimated at $79.33 \%$ in average.

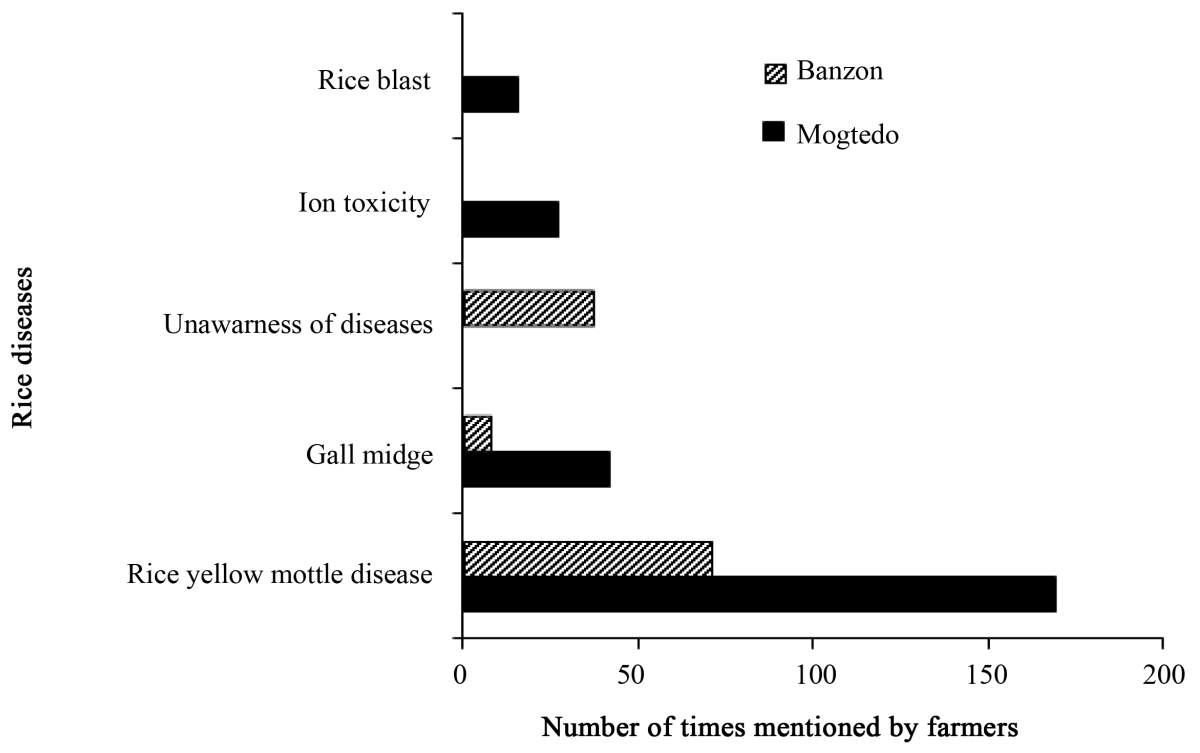

Figure 4. Farmers’ awareness of rice diseases in Banzon and Mogtedo.

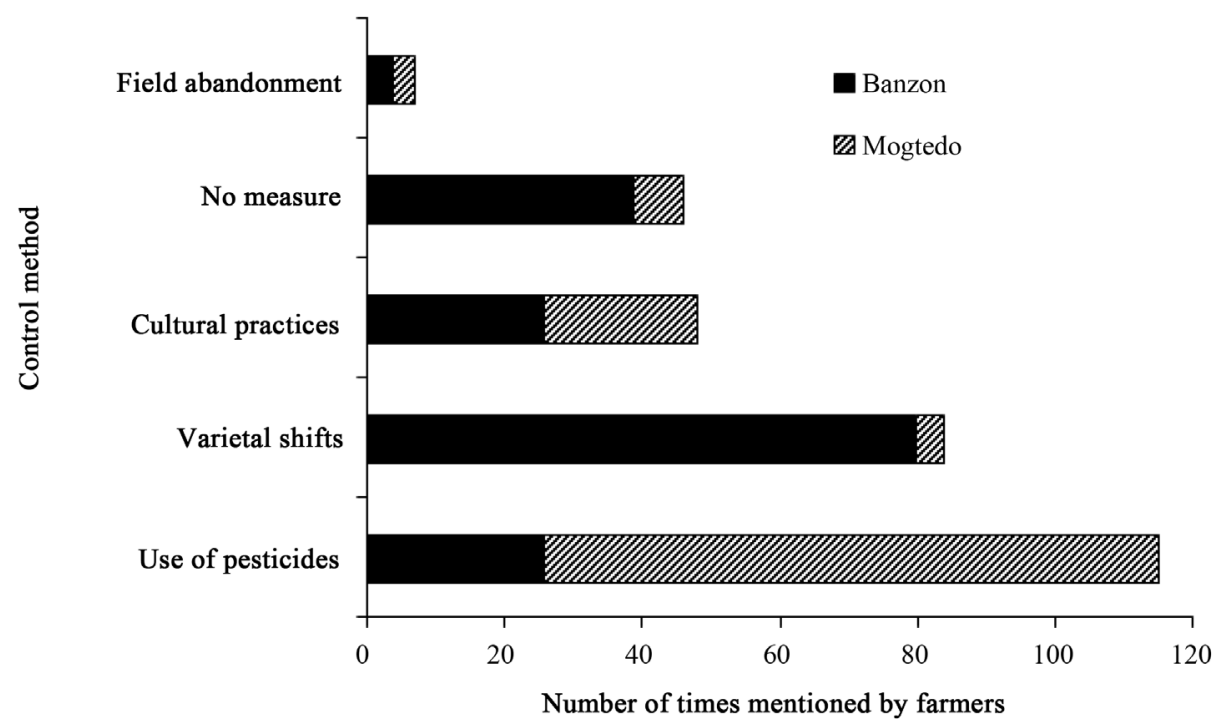

Figure 5. Rice yellow mottle control methods used by farmers in Banzon and Mogtedo. 
Table 1. Effect of rice yellow mottle disease on grain yield in three rice varieties.

\begin{tabular}{ccccccc}
\hline \multirow{2}{*}{ Variety } & \multicolumn{3}{c}{ Year 1 } & \multicolumn{2}{c}{ Year 2 } \\
\cline { 2 - 6 } & Healthy & Diseased & Yield loss (\%) & Healthy & Diseased & Yield loss (\%) \\
\hline FKR56N & $38.94 \mathrm{a}^{\mathrm{a}}$ & $4.40 \mathrm{a}$ & $88.70 \mathrm{a}$ & $35.83 \mathrm{a}$ & $7.30 \mathrm{a}$ & $79.63 \mathrm{a}$ \\
FKR62N & $47.33 \mathrm{~b}$ & $10.10 \mathrm{~b}$ & $78.66 \mathrm{a}$ & $47.23 \mathrm{~b}$ & $7.43 \mathrm{ab}$ & $80.14 \mathrm{a}$ \\
TS2 & $38.18 \mathrm{a}$ & $8.03 \mathrm{~b}$ & $78.97 \mathrm{a}$ & 35.59a & 10.50c & $70.50 \mathrm{a}$ \\
\hline
\end{tabular}

${ }^{a}$ Figures in the table represent means of per plant paddy rice yields in grams ( $\left.=50\right)$. Means within the same column followed by the same letter (s) are not significantly different $(\mathrm{P}=0.05)$, according to Fisher's LSD test.

Analysis of variance of per plant grain yield indicated significant effects of disease $(\mathrm{F}=1832.1 ; \mathrm{df}=1,600 ; \mathrm{P}<$ $0.0001)$ and rice variety $(\mathrm{F}=25.95 ; \mathrm{df}=2,600 ; \mathrm{P}<0.0001)$. There were also disease-variety $(\mathrm{F}=12.61 ; \mathrm{df}=2$, $600 ; \mathrm{P}<0.001)$ and disease-year $(\mathrm{F}=6.35$; $\mathrm{df}=1,600 ; \mathrm{P}=0.012)$ interactions, indicating that the effect of disease on yield depended on varieties and year of production. In the first year, diseased plants of rice varieties TS2 and FKR62 yielded twice more than those of FKR56N. By contrast, higher yields were found in TS2 only during the second year.

The levels of rice yellow mottle disease infections in Banzon were moderate. Disease incidence was evaluated at 29.54\% in 2010 and $26.98 \%$ in 2011. The difference in disease incidence was not significant $(\mathrm{F}=0.19$; $\mathrm{df}=1$; $\mathrm{P}=0.67$ ), indicating consistent epidemic levels over the two years. Taking into account the average yield loss assessed earlier, observed disease incidences would give extrapolated yield loss of 22.33\% per year in Banzon perimeter.

\section{Discussion}

The two study areas had contrasted ecologies and rice growing systems. Rice cultivation in both areas was at subsistence levels. Most farmers held small fields, and also (76\%) had low yields of 1 - 2 t/ha, which is consistent with the results reported for the whole West Africa [25]. Almost all farmers practiced mixed cropping. The strategy of growing several crops has been considered as a way to improve resilience [26]. However it may prevent farmers to focus sufficiently on adequate production of one particular crop, which rice intensification could benefit from. Altogether, features of rice cultivation observed here reflected a more general situation common to SSA which also applies to other major crops like maize, sorghum, cassava, etc. [27]. For rice in particular, [23] reported that rice farming in the Ivory Coast was dominated by small scale farmers with minimal external fertilizer input and very little technical assistance from extension agents. Similar characteristics were found in the present study, as the vast majority of farmers (98.5\%) held small plots of less than 5 ha and technical assistance was stated as a constraint, particularly at Mogtedo. However, efforts are being put in place for more support to farmers by providing them with improved and quality rice seeds and fertilizers along with closer technical assistance.

At both Banzon and Mogtedo, several rice varieties were grown by farmers on a regular basis, irrespective of recommendations from extension agents. By growing several varieties, farmers adopted the same resilience strategy for rice as for other crops. As such, based on their own empirical knowledge one particular farmer would grow at least two rice varieties, one early maturing though usually low yielding and one late maturing. This strategy was clearly exemplified by the choice of FKR18 and FKR19 as top varieties by farmers at Banzon and Motgedo, lends credence to this assertion. FKR18 was considered by farmers as high yielding with good taste at Banzon but needed more water than FKR19. As for Mogtedo farmers whose main concern was water availability, FKR19 was their top variety because of its better resistance to drought as well as its capability to be grown under irrigated and rainfed conditions.

NERICA varieties were among top farmers' preferred rice varieties. Indeed, successful promotion strategies were put in place by AfricaRice through participatory variety selection work involving female and male farmers after the development of these varieties [3]. The national research team also provided strong advertising locally. In the present study, women only represented a small proportion of farmers despite the promotion of several women farmers’ organizations in Mogtedo. However they may have played a significant role in the adoption of varieties through the appreciation of post-harvest processing properties. Possibly, the utmost reason for choosing NERICA varieties was their good yields as indicated by farmers who experienced 3 - 5 t/ha. These data are con- 
sistent with the potential yields of 5 - $7 \mathrm{t} / \mathrm{ha}$ [28] as on-farm yields were usually found to be lower than potential yields [29]. Results on yield loss assessment (Table 1) confirmed the higher performance of FKR62N as quoted by farmers during the survey. Although NERICA varieties were highly preferred by farmers, they were not the top preferred neither at Banzon nor at Mogtedo. According to farmers, FKR18, the top preferred variety at Banzon was one of the recommended rice varieties about 30 years ago. Later on, technical assistance dissuaded farmers from growing it because of its high susceptibility to rice blast despite the high yield potential of $5-6 \mathrm{t} / \mathrm{ha}$. NERICA varieties which exhibited moderate resistance to this disease [28] were deployed but farmers kept growing FKR18 for primarily for its good taste. A similar behavior was observed in 2002 in Mali where rice variety BG90-2 was grown by some farmers for their own consumption because of its good taste while varieties recommended for rice yellow mottle disease management purpose were grown for market (unpublished data). The choice of FKR 19 as top preferred variety at Mogtedo did not follow the same rationale. Taken together water shortage constraint and need for getting good yields, FKR19 appeared to be the best choice in that locality.

Rice diseases were reported by farmers as very important constraints. The opposite opinion was reported eighteen years ago in Ivory Coast where only a small proportion of farmers (9\%) mentioned diseases among major constraints in rice [23]. Farmers' unawareness of diseases was one of the main reasons for the low level of importance they attached to such constraints. Hence, farmers usually mistook diseases for soil infertility. Recently, farmers and extension agents were involved in routine trainings with the goal of improving rice production. These trainings allowed several farmers to be more and more acquainted with diseases including rice yellow mottle, rice blast, African gall midge, particularly at Banzon and other main irrigated rice areas. Nonetheless, lack of knowledge on rice diseases was perceivable especially at Mogtedo, which may have lowered the proportion of farmers considering diseases as constraints.

Farmers recognized RYMD as the most important rice disease but control measures applied were not effective. Due the complexity of disease epidemiology, Traore et al. [20] argue that an integrated disease management approach combining the deployment of resistant cultivars with prophylactic measures should be implemented. Although economically unfeasible and environmentally-unfriendly, the use of pesticides by farmers possibly had some effect on insect vectors. Effectiveness of varietal shift would have been significant if farmers' varieties were resistant to the disease. Unfortunately, all rice varieties, including NERICA varieties were severely affected by the disease, indicating their quite high susceptibility.

Yield loss assessment due to RYMD on three rice varieties indicated the high yield reduction of the disease whatever the variety. Average per plant yield was estimated at $79.33 \%$ with an extrapolated overall yield loss of $22.3 \%$ based on disease incidence in the fields. Such moderate level of yield loss was less than losses ranging from 58\% - 82\% reported during severe epidemics [12] [13]. This was consistent with relatively low disease incidence observed in the fields and indicated that the surveys were done in low epidemic years.

\section{Conclusion}

As for any crop, adoption of rice varieties by farmers is linked to criteria which may vary according to local conditions. This study indicated yield and marketability as common preference attributes. However, crop duration was a main concern in the dryer rice growing perimeter of Mogtedo while taste was put forward by farmers in Banzon which was less prone to drought. Most farmers in the two localities are aware of rice pest and diseases, especially rice yellow mottle virus disease. However, pests and diseases are poorly managed and even sometimes mismanaged though uncontrolled pesticide treatments. As rice yellow mottle virus disease still remains a serious threat to rice cultivation with potential yield losses exceeding $70 \%$, farmers' awareness of the disease is an important step for its management. Building on farmer's knowledge of the disease and their preference criteria for rice varieties, efforts need to be undertaken by scientists to develop adequate integrated disease management strategies

\section{Acknowledgements}

We thank the Alliance for Green Revolution in Africa (AGRA) through the West Africa Centre for Crop Improvement (WACCI), University of Ghana for their financial support. We also acknowledge the financial support of USAID/ERA to M. Camara during his stay in Burkina Faso. Skillful technical assistance of Mr. Zongo Abdoulaye and Ms Ouedraogo Yéyé Simone is also acknowledged. 


\section{References}

[1] Ogunbayo, S.A., Ojo, D.K., Guei, R.G., Oyelakin, O. and Sanni, K.A. (2005) Phylogenetic Diversity and Relationship among Forty Rice Accessions Using Morphological and RAPDs Techniques. African Journal of Biotechnology, 4, 1234-1244.

[2] Ogunbayo, S.A., Ojo, D.K., Popoola, A.R., Sié, M., Sanni, K.A., Nwilene, F.E., et al. (2007) Genetic Comparisons of Landrace Rice Accessions by Morphological and RAPDs Techniques. Asian Journal of Plant Science, 6, 653-666. http://dx.doi.org/10.3923/ajps.2007.653.666

[3] Seck, P.A., Diagne, A., Mohanty, S. and Wopereis, M.C.S. (2012) Crops that Feed the World 7: Rice. Food Security, 4, 7-24. http://dx.doi.org/10.1007/s12571-012-0168-1

[4] Kouassi, N.K., N'guessan, P., Albar, L., Fauquet, C. and Ghesquiere, A. (2005) Distribution and Characterization of Rice Yellow Mottle Virus: A Threat to African Farmers. Plant Disease, 89, 124-133. http://dx.doi.org/10.1094/PD-89-0124

[5] Allarangaye, M.D., Traoré, O., Traoré, V.S.E., Millogo, R.J. and Konaté, G. (2006) Evidence of the Non-Transmission of Rice Yellow Mottle Virus through Seeds of Wild Host Species. Journal of Plant Pathology, 88, 307-313.

[6] Konaté, G., Sarra, S. and Traoré, O. (2001) Rice Yellow Mottle Virus Is Seed-Borne but Not Seed Transmitted in Rice Seeds. European Journal of Plant Pathology, 107, 361-364. http://dx.doi.org/10.1023/A:1011295709393

[7] Bakker, W. (1970) Rice Yellow Mottle, a Mechanically Transmissible virus Disease of Rice in Kenya. Netherlands Journal of Plant Pathology, 76, 53-63. http://dx.doi.org/10.1007/BF01974433

[8] Sarra, S., Overing, P., Guindo, S. and Peters, D. (2004) Wind-Mediated Spread of Rice Yellow Mottle Virus (RYMV) in Irrigated Rice Crops. Plant Pathology, 53, 148-153. http://dx.doi.org/10.1111/j.0032-0862.2004.00981.x

[9] Traore, O., Traore, M.D., Fargette, D. and Konate, G. (2006) Rice Seedbeds as a Source of Primary Infection by Rice Yellow Mottle Virus. European Journal of Plant Pathology, 115, 181-186. http://dx.doi.org/10.1007/s10658-006-9004-9

[10] Fomba, S.N. (1988) Screening for Seedling Resistance to Rice Yellow Mottle Virus in Some Rice Cultivars in Sierra Leone. Plant Disease, 72, 641-642. http://dx.doi.org/10.1094/PD-72-0641

[11] Konate, G., Traore, O. and Coulibaly, M.M. (1997) Characterization of Rice Yellow Mottle Virus Isolates in SudanoSahelian Areas. Archives of Virology, 142, 1117-1124. http://dx.doi.org/10.1007/s007050050146

[12] Reckhaus, P.M. and Adamou, I. (1986) Rice Diseases and Their Economic Importance in Niger Food and Agriculture Organization. FAO Plant Protection Bulletin, 34, 77-82.

[13] Taylor, D.R., Fofie, A.S. and Suma, M. (1990) Natural Infection of Rice Yellow Mottle Virus Disease (RYMV) on Rice in Sierra Leone. International Rice Research Newsletter, 15, 5-19.

[14] Rakotomalala, M., Pinel-Galzi, A., Albar, L., Ghesquière, A., Rabenantoandro, Y., et al. (2008) Resistance to Rice Yellow Mottle Virus in Rice Germplasm in Madagascar. European Journal of Plant Pathology, 122, 277-286. http://dx.doi.org/10.1007/s10658-008-9282-5

[15] Thiémélé, D.B., Ndjiondjop, M.N., Cheron, S., Séré, Y., Aké, S., et al. (2010) Identification of a Second Major Resistance Gene to Rice Yellow Mottle Virus, RYMV2, in the African Cultivated Rice Species, O. glaberrima. Theoretical and Applied Genetics, 121 169-179. http://dx.doi.org/10.1007/s00122-010-1300-2

[16] Ndjiondjop, M.N., Albar, L., Fargette, D., Fauquet, C. and Ghesquiere, A. (1999) The Genetic Basis of High Resistance to Rice Yellow Mottle Virus (RYMV) in Cultivars of Two Cultivated Rice Species. Plant Disease, 83, 931-935. http://dx.doi.org/10.1094/PDIS.1999.83.10.931

[17] Thottappilly, G. and Rossel, H.W. (1993) Evaluation of Resistance to Rice Yellow Mottle Virus in Oryza Species. Indian Journal of Virology, 9, 65-73.

[18] Sorho, F., Pinel, A., Traoré, O., Bersoult, A., Ghesquière, A., et al. (2005) Durability of Natural and Transgenic Resistances in Rice to Rice Yellow Mottle Virus. European Journal of Plant Pathology, 112, 349-359. http://dx.doi.org/10.1007/s10658-005-6607-5

[19] Traoré, O., Pinel, A., Hebrard, E., Gumedzoé, Y.D., Fargette, D., et al. (2006) Occurrence of Resistance-Breaking Isolates of Rice Yellow Mottle Virus in West and Central Africa. Plant Disease, 90, 259-263. http://dx.doi.org/10.1094/PD-90-0259

[20] Traore, O., Pinel-Galzi, A., Sorho, F., Sarra, S., Rakotomalala, M., et al. (2009) A Reassessment of the Epidemiology of Rice Yellow Mottle Virus Following Recent Advances in Field and Molecular Studies. Virus Research, 141, 258267. http://dx.doi.org/10.1016/j.virusres.2009.01.011

[21] Abo, M.E., Sy, A.A. and Alegbejo, M.D. (1998) Rice Yellow Mottle Virus (RYMV) in Africa: Evolution, Distribution, Economic Significance and Sustainable Rice Production and Management Strategies. Journal of Sustainable Agriculture, 11, 85-111. http://dx.doi.org/10.1300/J064v11n02_08 
[22] Roling, N. and Van Der Fliert, E. (1994) Transforming Extension for Sustainable Agriculture: The Case of Integrated Pest Management in Rice in Indonesia. Agriculture and Human Values, 11, 96-108. http://dx.doi.org/10.1007/BF01530451

[23] Adesina, A.A., Johnson, D.E. and Heinrichs, E.A. (1994) Rice Pests in the Ivory Coast, West Africa: Farmers’ Perceptions and Management Strategies. International Journal of Pest Management, 40, 293-299. http://dx.doi.org/10.1080/09670879409371902

[24] Warton, D.I. and Hui, F.K.C. (2010) The Arcsine Is Asinine: The Analysis of Proportions in Ecology. Ecology, 92, 310. http://dx.doi.org/10.1890/10-0340.1

[25] Saito, K., Sokei, Y. and Wopereis, M.C.S. (2012) Enhancing Rice Productivity in West Africa through Genetic Improvement. Crop Science, 52, 484-493. http://dx.doi.org/10.2135/cropsci2010.12.0734

[26] Lin, B.B. (2011) Resilience in Agriculture through Crop Diversification: Adaptive Management for Environmental Change. Bioscience, 61, 183-193. http://dx.doi.org/10.1525/bio.2011.61.3.4

[27] Fermont, A.M., Van Asten, P.J.A., Tittonell, P., Van Wijk, M.T. and Giller, K.E. (2009) Closing the Cassava Yield Gap: An Analysis from Smallholder Farms in East Africa. Field Crops Research, 112, 24-36. http://dx.doi.org/10.1016/j.fcr.2009.01.009

[28] Sie, M., Kabore, B., Dakouo, D., Dembele, Y., Segda, Z., et al. (2007) Release of Four New Interspecific Varieties for the Rainfed Lowland in Burkina Faso. International Rice Research Newsletter, 32, 16-17.

[29] Becker, M., Johnson, D.E., Wopereis, M.C.S. and Sow, A. (2003) Rice Yield Gaps in Irrigated Systems along an AgroEcological Gradient in West Africa. Journal of Plant Nutrition and Soil Science, 166, 61-67. http://dx.doi.org/10.1002/jpln.200390013 